\title{
Work in Progress: Implementation of Peer Review to Enhance Written and Visual Communication Learning in Bioengineering Capstone Reports
}

\section{Dr. Stephanie Pulford, Center for Engineering Learning and Teaching (CELT)}

Dr. Stephanie Pulford is an instructional consultant within University of Washington's Center for Engineering Teaching \& Learning, where she coordinates the Engineering Writing \& Communication Development Program. Dr. Pulford's professional background in engineering includes a Ph.D. in Mechanical Engineering, an M.S. in Engineering Mechanics, and a B.S. in Aerospace Engineering as well as industry experience as an aircraft engineer. Her research and professional interests include faculty development, innovations in engineering communication education, engineering student learning motivation, and narrative structure in technical communication.

\section{Dr. Alyssa Catherine Taylor, University of Washington}

Alyssa C. Taylor is a lecturer in the Department of Bioengineering at the University of Washington. She received a B.S. in biological systems engineering at the University of California, Davis, and a Ph.D. in biomedical engineering at the University of Virginia. Taylor's teaching activities are focused on developing and teaching core introductory courses and technical labs for bioengineering undergraduates, as well as coordinating the capstone design sequence for the BIOE Department at the University of Washington. Taylor currently pursues educational research and continuous improvement activities, with the ultimate goal of optimizing bioengineering curriculum design and student learning outcomes. 


\section{Work in Progress: Implementation of Peer Review to Enhance Written and Visual Communication Learning in Bioengineering Capstone Reports}

Engineering undergraduate curricula must foster students' development of effective communication skills along with technical skill development. The senior capstone report often plays an instrumental role in this development, since it comprises both the final assessment of student communication performance and also students' most significant opportunity for active learning of in-discipline communication skills. Peer review has been proposed as an ideal means to provide students with much-needed feedback toward this communication learning. Peer review also has the potential to increase students' interpersonal communication skills and metacognition, provided that the review activity is structured to encourage constructive contributions and reflection[1]. The goal of this work-in-progress project is to implement a peer review strategy, integrated throughout the yearlong capstone experience, so that students can obtain significant, formative feedback and build transferable communication skills and insights.

\section{Workshop Series Description}

The students in our Bioengineering capstone will complete a five-session workshop series of scaffolded communication critique, small-group formative peer review, and class reflection. Through the series, they will be guided to collaborate as a class to generate their own rubric for sections of the capstone. The students will then use these codes to provide constructive feedback to one another in small groups. The groups will reconvene to share each other's successful techniques to the class, and the class will be prompted to reflect on these successes and use them to generate ideas to improve their own work.

The novelty of our specific approach lies in the combination of three qualities:

- The degree of student contribution to setting standards for effective writing and effective critique. This gives students ownership and a stake in these standards, as well as providing scaffolding for critical thought about quality in professional communication.

- The degree of scaffolding undergirding the students' critique activity. A frequent criticism of peer review activities are that student reviewers, left to their own devices, are unconstructive, discouraging, and perhaps even misleading[1-3]. We provide students with a structure that helps them stay focused and give helpful critiques.

- The degree of reflection required of students, toward learning, retaining and transferring their in-workshop learning. Our activity asks students to identify, share, and apply lessons learned from others' projects, particularly successes.

Participants: Bioengineering senior undergraduates at the University of Washington participate in a Capstone Design course, which supports capstone research with weekly 50 minute meeting. We utilize those meetings for our workshop sessions, extending the class period as necessary. To facilitate the effective drafting of this 50-page capstone report and provide students with feedback on their writing, we are implementing a peer review strategy in which each academic quarter involves workshops to address specific components: 
Autumn Quarter Workshop 1: Generation of Standards for Effective Writing (50 min.) Objective: Students reflect upon their own experience as readers of scientific literature in order to articulate which qualities make an effective introduction and methods sections.

Activation: The facilitator led the students to discuss their user experiences reading two assigned papers, and also performing a literature review for their capstone.

Learning Activity: Students identified qualities that made good Introduction and Methods sections in small groups. After ten minutes of group discussion, groups reported back to the class, to make a master list. From this, the class chose five to become the basis of a rubric.

Call To Action: Students were asked to use the rubric to revise their drafts.

Autumn Quarter Workshop 2: Expectations for Conduct and Useful Feedback during Peer Review; Group Peer Review Activity (75 min.)

Objective: Students provide meaningful guided peer review discussions of drafts.

Activation: The facilitator asked for feedback on prior peer review experiences to uncover what made for useful feedback; and the class established rules of conduct collaboratively.

Learning Activity: Guiding questions for the peer review activity were put on the board for reference. Groups of three students discussed each contributor's paper in turn (10 minutes each). Call To Action: Students were asked to revise their drafts in light of the peer review feedback.

Winter Quarter Workshops 3 and 4: Explanation of the Design Section of Capstone Report These workshops are similar in structure to Workshops 1 and 2.

Workshop 3: The facilitator guides students in a discussion of the design section. Similarly to the first workshop, the class generates new priorities to be used for a rubric.

Workshop 4: Using guiding questions and the Design section rubric, groups of three students discuss each paper's design section (20 minutes each). Afterwards, the full class participated in a discussion based on a reflective prompt, "Tell us something positive you saw in another student's paper, so that we can all learn from it" (Figure 1).

Spring Quarter Workshop 4: Design Principles in Figures (50 min.) Students are led in a class discussion to identify and understand visual design principles.

Spring Quarter Workshop 5: Peer Critique of Capstone Report Figures (50 min.)

The spring quarter program on figure design and critique was offered first in 2014; for more information see work by the same authors[4].

Prompt: "Tell us something positive you saw in another student's paper, so that we can all learn from it."

- "My partner very clearly laid out the gap in technology in his Introduction, and justified the need for his own project strongly."

- "My partner used a flowchart to summarize his method. It made the method clear and easy to understand."

- "My partner used a table to organize dense information in the Design section. I could refer to it easily and read it quickly."

Figure 1:

Sample in-

class

discussion

responses to

reflective

prompt

- "My partner did a great job of summarizing within subsections, so that I had the context for all of the design decisions that he made." 


\section{Assessment Results}

After completion of the two autumn quarter workshops, students were asked to complete an anonymous on-line survey regarding their perceptions of the workshops (Figure 2). Surveys were completed by $72 \%$ of students (33/46). Only one student answered "Disagree" or "Strongly Disagree" for all three assessment questions. Students also provided extensive comments with regards to aspects were helpful to their learning and writing and what could be changed to help their learning (Figure 3). The most notable result of student feedback was that students would prefer to have twenty minutes rather than ten to discuss one another's papers; the observed level of engagement in the classroom during the peer review activity corroborated students' report that they were having more detailed discussions than ten minutes permitted. Students also agreed that they'd prefer a chance to read classmates' work ahead of the student review.

\begin{tabular}{|c|c|c|c|c|}
\hline $100 \%$ & & & \multirow{11}{*}{$\begin{array}{l}\text { Strongly Disagree } \\
\square \text { Disagree } \\
\square \text { Agree } \\
\square \text { Strongly Agree }\end{array}$} & \multirow{11}{*}{$\begin{array}{l}\text { Figure } 2 . \\
\text { Ratings } \\
\text { submitted by } \\
\text { students in } \\
\text { response to } \\
\text { questions } \\
\text { regarding the } \\
\text { autumn series } \\
\text { workshops }\end{array}$} \\
\hline $90 \%$ & & & & \\
\hline $80 \%$ & & & & \\
\hline $70 \%$ & & & & \\
\hline $60 \%$ & & & & \\
\hline $50 \%$ & & & & \\
\hline $40 \%$ & & & & \\
\hline $30 \%$ & & & & \\
\hline $20 \%$ & & & & \\
\hline $10 \%$ & & & & \\
\hline $\begin{array}{l}0 \% \\
\text { Discus } \\
\text { Intro/N } \\
\text { clarify } \\
\text { approa }\end{array}$ & $\begin{array}{l}\text { I obtained feedback that } \\
\text { helped/will help me } \\
\text { improve my draft }\end{array}$ & $\begin{array}{l}\text { Providing feedback to others } \\
\text { helped me to clarify my } \\
\text { thoughts and/or approach to } \\
\text { writing my draft }\end{array}$ & & \\
\hline
\end{tabular}

- "Discussing what makes a good paper was very helpful to me in writing my draft. It gave me an idea of what the paper should contain and how it should be formatted in order for it to be effective."

- "I really enjoyed the 3 person group dynamics and felt it was an effective conduit for giving feedback."

- "I thought it was good to be able to take with outer people about my work and some of the decisions I made in how to write each section and get some feedback on that."

- "Having the opportunity to have my papers read by my peers gave me an idea on what I exactly needed to improve on. This workshop was a great asset to my growth in writing."

Figure 3.

Sample student feedback comments. 
Future Assessment Plan: During the second quarter of workshops, students were asked to upload a copy of their draft before peer review. These will be compared to the revised drafts that students will submit at the end of the quarter, in order to examine the changes made as a result of the peer review workshop.

\section{Discussion and Conclusion}

Based on overall positive student response, our first offering of a peer review workshop is a promising answer to students' interest in more feedback and guidance on writing in their senior year. Students' request for more time and means to engage with one another's work, combined with positive feedback, suggests that they value the activity and take their roles as peer reviewers seriously. By scaffolding student engagement in this way, we enrich their learning experience not only with information they can use toward capstone report performance. We also provide an authentic opportunity for students to analyze documents and construct standards when no clear rubric has been provided, providing practice for the communication challenges that most engineers encounter in their professional careers.

\section{Bibliography}

[1] K. Topping, "Peer Assessment Between Students in Colleges and Universities," Review of Educational Research, vol. 68. pp. 249-276, 1998.

[2] K. Cho, C. D. Schunn, and R. W. Wilson, "Validity and reliability of scaffolded peer assessment of writing from instructor and student perspectives.," Journal of Educational Psychology, vol. 98. pp. 891-901, 2006.

[3] N. Falchikov, "Peer Feedback Marking: Developing Peer Assessment," Innovations in Education \& Training International, vol. 32. pp. 175-187, 1995.

[4] S. Pulford and A. C. Taylor, "Visual Communication Learning through Peer Design Critiques: Engineering Communication Across Divisions," in Proceedings of the 2015 American Society for Engineering Education Annual Conference, 2015. 